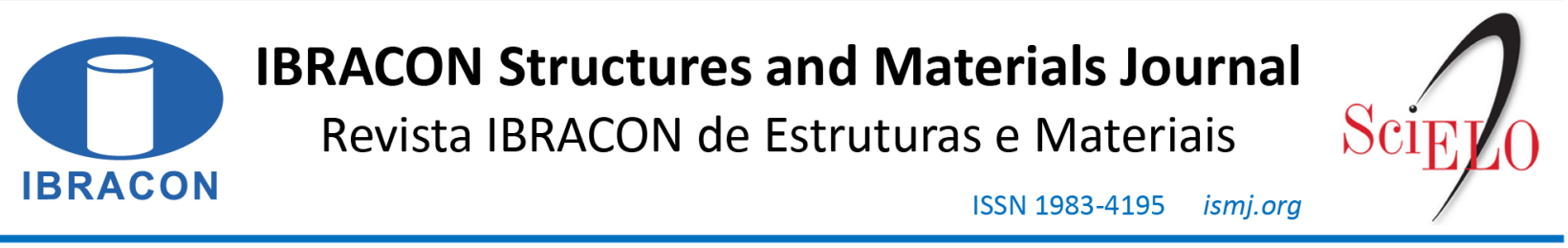

ORIGINAL ARTICLE

\title{
Effects of alkali-silica reaction on mechanical behavior of four-pile caps
}

\section{Efeitos da reação álcali-sílica no comportamento mecânico de blocos sobre quatro estacas}

Christiane Mylena Tavares de Menezes Gameleira ${ }^{\mathrm{a}}$ (D)

Valmiro Quéfren Gameleira Nunes ${ }^{\mathrm{a}}$ (D)

Paulo de Araújo Régis ${ }^{\mathrm{a}}$

Paulo Marcelo Vieira Ribeiro ${ }^{\mathrm{a}}$ (D)

Arnaldo Manoel Pereira Carneiro ${ }^{\mathrm{a}}$ (iD)

Romilde Almeida de Oliveira ${ }^{b}$

Received 10 August 2019

Accepted 30 January 2020

\author{
${ }^{a}$ Universidade Federal de Pernambuco - UFPE, Departamento de Engenharia Civil, Recife, PE, Brasil \\ ${ }^{b}$ Universidade Católica de Pernambuco - UNICAP, Departamento de Engenharia Civil, Recife, PE, Brasil
}

\begin{abstract}
The structural behavior resulting from alkali-aggregate reactions on four-pile caps was numerically studied using software based on the Finite Element Method. The cracking was analyzed in terms of reduction rates in the mechanical properties of the concrete (compressive strength, tensile strength and modulus of elasticity) as a consequence of the expansion induced by the alkali-aggregate reaction (AAR) referred to in the literature. One option for dealing with changes in mechanical properties, reported as influenced by the reactive aggregate type, environmental conditions and stress state, is to directly use the value of the properties of the material tested in the analysis, an approach adopted in the study and implemented in the analysis. From the results found in the analysis program the three main effects of AAR could be better understood: expansion, cracking and degradation of mechanical properties of concrete.
\end{abstract}

Keywords: concrete, alkali-aggregate reaction, pile caps, mechanical properties, numerical analysis.

Resumo: Estudou-se numericamente o comportamento estrutural resultante de reações álcali-agregado em blocos sobre quatro estacas utilizando software baseado em Método dos Elementos Finitos. Analisou-se a fissuração considerando taxas de reduções nas propriedades mecânicas do concreto (resistência à compressão, resistência à tração e módulo de elasticidade) consequentes da expansão induzida pela reação álcali-agregado (RAA), existentes na literatura. Uma opção para lidar com as mudanças nas propriedades mecânicas, relatadas como influenciadas pelo tipo de agregado reativo, pelas condições ambientais e pelo estado de tensão consiste em usar diretamente o valor das propriedades do material testado na análise, abordagem que foi adotada na pesquisa e implementada no programa de análise. A partir dos resultados encontrados foi possível compreender melhor os três principais efeitos da RAA: expansão, fissuração e degradação das propriedades mecânicas do concreto.

Palavras-chave: concreto, reação álcali-agregado, blocos sobre estacas, propriedades mecânicas, análise numérica.

How to cite: C. M. T. M. Gameleira, V. Q. G. Nunes, P. A. Régis, P. M. V. Ribeiro, A. M. P. Carneiro, and R. A. Oliveira, "Effects of alkali-silica reaction on mechanical behavior of four-pile caps," Rev. IBRACON Estrut. Mater., vol. 13, no. 4, e13408, 2020, https://doi.org/10.1590/S198341952020000400008 


\section{INTRODUCTION}

Assessment of damage to AAR-affected concrete generally depends on the measurement of the expansion, monitoring of cracks and testing the concrete properties. It is well established that sound conventional concrete has high compressive strength and modulus of elasticity, low tensile strength, poor response to uniaxial load (compressive or tensile) and increased ductility and strength (compressive and tensile) in a confined environment. This sensitivity to the confinement state is linked to the presence of minor defects, or even microcracking, which will exist in the concrete. So, even for a non-deteriorated concrete in a triaxial compression state, there will always be local zones in stress within the volume of the material due to its heterogeneous and defective nature.

The literature includes several experimental studies on the alkali-aggregate reaction, namely Gomes [1], for example, who studied experiments on the structural recovery of foundation caps; Sanchez et al. [2] addressed a new method called the accelerated Brazilian concrete prism test (ABCPT), in which the results indicated that that test had great potential to detect aggregate reactivity in current engineering projects; Sanchez et al. [3], who presented test results from the Stiffness Damage Test (SDT) and the microscopic evaluation of the Damage Rating Index (DRI) to assess the level of damage to the AAR-affected concrete. However, there are only a few numerical studies on expressions of such reactions on foundation caps. The purpose of this paper, therefore, is to numerically study the effect of the reductions on the concrete's mechanical properties (compressive strength, tensile strength and modulus of elasticity) as a result of the AAR-induced expansion in the cracking results in four-pile foundation caps and was based on Gameleira's thesis of doctorate [4]. Moreover, a numerical simulation on the AAR effect on concrete structures is a valuable tool to predict damage, specify repairs and act as support for standard modifications related to structural designs.

\section{METHODOLOGY}

The methodology consisted of bibliographic research in order to find a theoretical basis for the AAR. It is necessary to have a better understanding of the numerical models presented and the parameters used for each of them. Soon after, from results obtained using analytical models, a numerical analysis was undertaken using the DIANA program [5], [6] ,[7], based on the finite element method.

For a numerical analysis the behavior of the material was adopted as non-linear. The results of interest were a distribution of cracks and cracking fields of the models in order to study the influence of the variation of the mechanical properties on the materials at different expansion levels.

\subsection{Alterations to the design mechanical parameters as a result of AAR}

The fact that AAR has harmful impacts on the mechanical properties of the concrete structures is a problem apparent after many investigations. ASTM C1293 [8] and the Canadian CSA-A23.2-14A [9] describe aggregates that cause expansion of more than $0.04 \%$ in the concrete as a potentially harmful reaction [10].

In Marzouk and Langdon [11], normal highly resistant concretes show, under the AAR action, a drop in compressive and tensile strength and in the modulus of elasticity, with the modulus of elasticity as the most affected property, since it depends more on changes to the concrete's microstructure.

When studying concrete samples taken from the drainage gallery of Furnas hydropower plant in Rio Grande, municipality of Alpinopolis (Minas Gerais state), in a study submitted by Hasparyk [12], there was a sharp drop in the modulus of elasticity, but no major alterations to the compressive strength.

Both Hoobs [13] and Larive [14] show the fall in the modulus of elasticity in AAR presence. St. John [15] noted a reduction in the tensile strength value when studying airport runways.

Generally AAR causes a very sharp drop in terms of tensile strength and modulus of elasticity. These two properties are far more affected than compressive strength, which only begins to drop significantly with high expansion levels [16]-[19]. The classic AAR effect on the aforementioned concrete's mechanical properties suggests that microcracking caused by this harmful mechanism can be identified even before the material reaches significant expansion and macrocracking and, possibly, a significant loss of compressive strength [16]. According to ISE [20], the compressive strengths would normally increase in concrete structures exposed to the natural environmental conditions to reach figures beyond the design values ( 28 days); thus, the loss of compressive strength due to AAR is generally less or similar to the difference between the design and actual strength values measured at any given moment. On the other hand, a significant loss of compressive strength may be found for concrete elements undergoing major expansions (that is, $1 \mathrm{~mm} / \mathrm{m}$ or $0.10 \%$ ) [21]-[23]. According to these authors, for expansions of $0.10 \%$ or less, it is very likely that the 
concrete element, or even the structure, efficiently withstands their active stresses. However, after a $0.30 \%$ expansion, a structural evaluation must be undertaken [21]-[23].

Furthermore, Kubo and Nakata [24] reported the results of recent studies showing losses of compressive strength for concretes with expansion levels of more than $0.30 \%$. For expansion levels of $0.50 \%$, the authors observed around $30 \%$ losses of compressive strength. In the same study, the authors discovered that neither the water-cement ratio of the concrete mixes nor the aggregates deployed had a significant influence on the compressive strength, at least to the expansion levels of $0.30 \%$. On the other hand, researchers found major differences in the stress/strain behavior (especially for the modulus of elasticity) at similar expansion levels when different reactive aggregates were used. They associated these differences to different crack patterns when different reactive aggregates are used in concrete [24].

However, Naar [25] suggested that the analysis of the reductions in the mechanical properties due to AAR is complicated and many contradictory results feature in the literature. In terms of compressive strength, some authors found losses only at very high expansion levels. In contrast, others found almost no change, or even an increase, in the compressive strength with the expansion increase due to AAR. Considering the loss of the modulus of elasticity, most authors agree with a rapid loss even at low expansion levels ( $0.0 \%$ to $0.05 \%)$; losses were reported varying from $20 \%$ to $80 \%$ of the modulus of elasticity of non-reactive concretes, considered to be a huge variation.

Sanchez et al. [26] measured the influence of the type and nature of the aggregates, together with the sample's compressive strength, in the mechanical properties of the AAR-affected concrete. Three concrete types were used in this study $(25,35$ and $45 \mathrm{MPa})$, based on which approximately 765 cylindrical test samples $(100 \mathrm{~mm} \times 200 \mathrm{~mm}$ in size $)$ were molded and then stored in conditions that allow AAR development. When the test samples reached the four expansion levels chosen for this study $(0.05 \%, 0.12 \%, 0.20 \%$ and $0.30 \% ; \pm 0.01 \%)$, they underwent the stiffness damage test (SDT). The concrete test samples were examined petrographically at the same expansion levels mentioned above, in order to determine the degree of their physical damage. The mixes were tested with the aggregates. The authors discovered that the modulus of elasticity and tensile strength are, in fact, more strongly affected than the compressive strength, but the compressive strength at higher expansion values may drop sharply (30\% or less). It was discovered that the last property is related to the microscopic characteristics of AAR deterioration, which tend to start inside the aggregate particles and spread to the cement paste only at moderate and high expansion levels.

Gorga [27] measured the effect of the consequences of the AAR-induced expansion in the mechanical properties of the concrete (compressive strength, tensile strength and modulus of elasticity). These properties are reduced over time and are the direct consequence of physical degradation (that is, cracking) inside the aggregate particles and cement paste.

It is, therefore, evident that the deterioration of the concrete's mechanical properties is a very important phenomenon directly related to the expansion level, type and nature of the aggregate and compressive strength of the material. Today, however, there is very restricted information about the ratio between the development of the AAR micromechanical characteristics and the losses in the mechanical properties of the AAR-affected concrete.

\subsection{Numerical analysis}

The DIANA software (DIsplacement ANAlyzer) used in the study is a finite element software package based on the displacement method.

The program has been developed since 1972 by engineers from TNO Building and Construction Research Company (Netherlands) and is a powerful tool for concrete simulation, considering complex effects such as cracking, creep, shrinkage, curing, temperature effects, instability, and so on.

DIANA uses parameters of fracture mechanics to describe this behaviour of the concrete. To study concrete cracking the program provides discrete models with interface elements or distributed crack models in fixed or rotational directions.

In the study the distributed crack model was used as being the easiest. The parameters required for the model are as follows: fracture energy in Gf stress (energy required for a unit area of crack), fracture energy in Gc compression, tensile and compressive strength, shear retention factor $\beta$ and length of crack band $h$.

Stoner [28] studied the approach of fracture energy to define the tensile behaviour of concrete in stirrup-less beams. Values were analysed provided by equations for estimating fracture energy, in the absence of the test, supplied by: Model Code 1990; Trunk and Wittmann [29], fib Bulletin 42 [30] and Model Code 2010 [31], and the conclusion was reached that the fracture energy calculated according to Model Code 1990 gave more accurate consistent results for all beams studied.

So, in this study the CEB Model Code 1990 [32] was used to estimate the fracture energy, and the Gf value was calculated using Equation 1. 
$G_{f}=G_{F 0} \cdot\left(\frac{f_{c k}}{f_{c m o}}\right)^{0.7}\left[N \cdot m m / m^{2}\right]$

where:

$f_{\text {cmo }}=10 \mathrm{MPa}$

$G_{F 0}=$ basic value of fracture energy, depends on the diameter of the aggregate (Table 1)

$f_{c k}=$ characteristic compressive strength of concrete, in $\mathrm{N} / \mathrm{mm}^{2}$

Table 1. GFo in function of the maximum diameter of the aggregate.

\begin{tabular}{cc}
\hline $\boldsymbol{d}_{\boldsymbol{m a x}}(\boldsymbol{m} \boldsymbol{m})$ & $\boldsymbol{G}_{\boldsymbol{F O}}\left(\boldsymbol{N} \cdot \boldsymbol{m} \boldsymbol{m} / \boldsymbol{m m}^{2}\right)$ \\
\hline 8 & 0.025 \\
\hline 16 & 0.030 \\
\hline 32 & 0.058 \\
\hline
\end{tabular}

Equation 2 calculated the crack band length, where $f_{t}$ is the tensile strength of the concrete and $\varepsilon_{u}$ the ultimate tensile strain of the concrete adopted at $0.238 \%$ (strain at yield level of a CA-50 steel bar)

$$
\begin{gathered}
\frac{G_{f}}{h}=\frac{\varepsilon_{u} \cdot f_{t}}{2} \\
h=\frac{2 \cdot G_{f}}{\varepsilon_{u} \cdot f_{t}}
\end{gathered}
$$

The value of the compressive fracture energy $G_{c}$, is between 10 and $25 \mathrm{~N} . \mathrm{mm} / \mathrm{mm}^{2}$ that corresponds to a value between 50 and 100 times $G_{f}$, as recommended by Feenstra and Borst [33].

The characteristics compressive strength of the concrete $f_{c k}$ was considered and the concrete's average tensile strength was calculated from the Equation 3 in NBR 6118 [34].

$f_{c t, m}=0.3 \cdot f_{c k}^{\frac{2}{3}}$, for concretes in classes of C50 or less.

The program provides two Total Strain models that are able to describe the concrete behavior under compressive and tensile stresses based on the stress-strain ratio: the Total Strain Rotating Crack Model and Total Strain Fixed Crack Model. These models satisfactorily represent the ultimate and service limit states of reinforced concrete structures.

The Total Strain Fixed Crack Model was used for the study, which stays in the crack direction as it spreads through the concrete.

The input data of this model are: longitudinal modulus of elasticity of the material, Poisson's ratio, tensile and compressive strength and the concrete compressive and tensile behavior curves.

For the study, the exponential curve for the concrete's tensile behavior and the parabolic curve for the concrete's compressive behavior were used.

The concrete numerical simulation adopted a 20-node isoparametric solid element with quadratic interpolation for displacement, HE20 CHX60. Each node represents three degrees of freedom, which are the displacements in x, y and z directions.

For reinforcement a resource of the program called embedded reinforcement was used, designed to stiffen the fine elements of the model. By fitting this resource into the mesh of finite elements representing the concrete, the software simulates the presence of reinforcement in that specific region. This method does not have its own degrees of freedom and, as a standard, its strains are counted from the strain field of the elements where it is inserted. This is why it cannot be considered a finite element. 
The reinforcement requires perfect adhesion between reinforcement and concrete, and only with the inclusion of interface elements is it possible to consider that the adhesion between reinforcement and concrete is not perfect. By means of "embedded reinforcements" non-linearity can be included in the reinforcement behavior, such as steel hardening and plasticization. The embedded reinforcements help in fast and simplified creation of the finite element mesh, attributing practicality to the model's creation.

This study involved the use of: Gc $=100 \mathrm{Gf}, \beta=0.99$ while the Regular Newton-Raphson method was used to solve non-linear equation systems, with an energy convergence criterion and tolerance of 0.1 .

The analysis adopted the following steps: definition of the properties of materials, type of finite element to be used, mesh, actions and contour conditions.

For the numerical simulation of the foundation caps complete models were used; that is, without taking into account the benefits introduced by symmetry.

The pile models were defined as rectangular to facilitate the construction of the numerical mesh. The piles and pillars were modeled with the height of the block, a procedure normally adopted in experimental tests.

A four-pile cap was used, undergoing the centered force action, with a square $40 \mathrm{~cm} \times 40 \mathrm{~cm}$ pillar and square piles with section $40 \mathrm{~cm} \times 40 \mathrm{~cm}$ and a failure load of $472 \mathrm{tf}$.

For the finite element mesh, a mapped mesh was chosen, to enable obtaining good results without needing a larger degree of discretization, which would not be possible when automatically using a mesh division. Every analysis was made with the size of the line divisions, that is, $50 \mathrm{~mm}$ distance between the nodes. For this division, 17545 nodes, 3984 elements and an average processing time of $5 \mathrm{~h} 30 \mathrm{~min}$ were created. Figure 1 shows the modeled caps with the mapped mesh and Figure 2 shows the cap reinforcements.

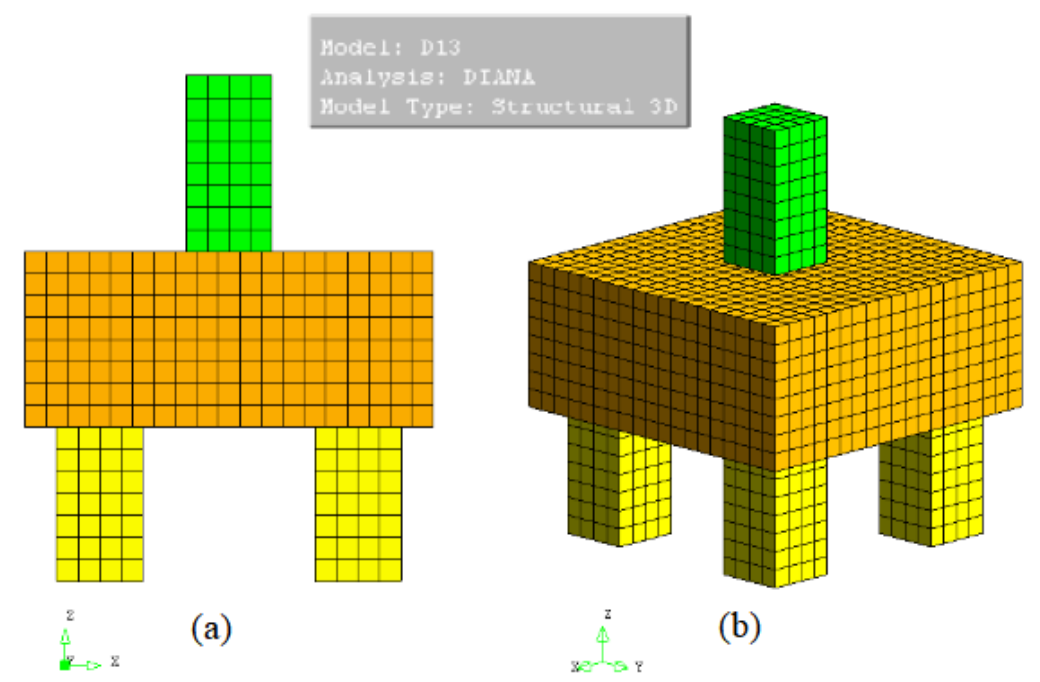

Figure 1. Finite element mesh. (a) front view and (b) perspective.

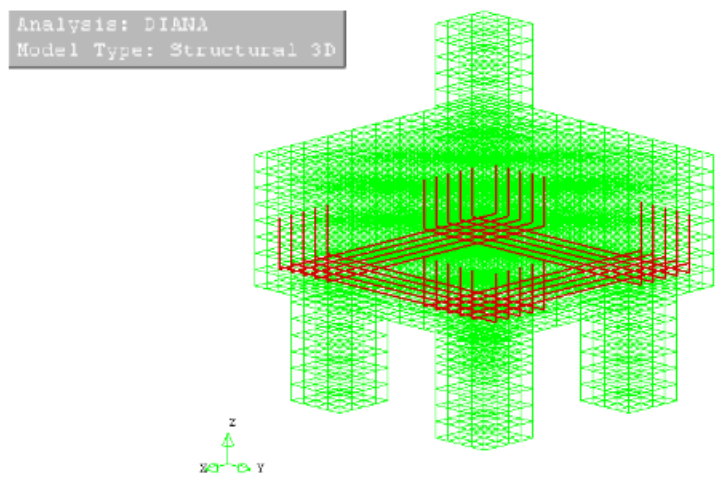

Figure 2. Reinforcement of four-pile caps. 
For the foundation caps, contour conditions were defined (Figure 3a) that restricted all nodes on the surface of the caps on plane $\mathrm{xz}$, in the two directions and in the normal direction to this plane; that is, the three directions were restricted. The intention of preventing model rotation is due to the idea of studying the cap behavior, keeping conditions coherent with those of an experimental test. For the loading condition (Figure 3b), applying an action in form of distributed pressure on the top cross-section area of the pillar was considered, in a negative direction of $z$.

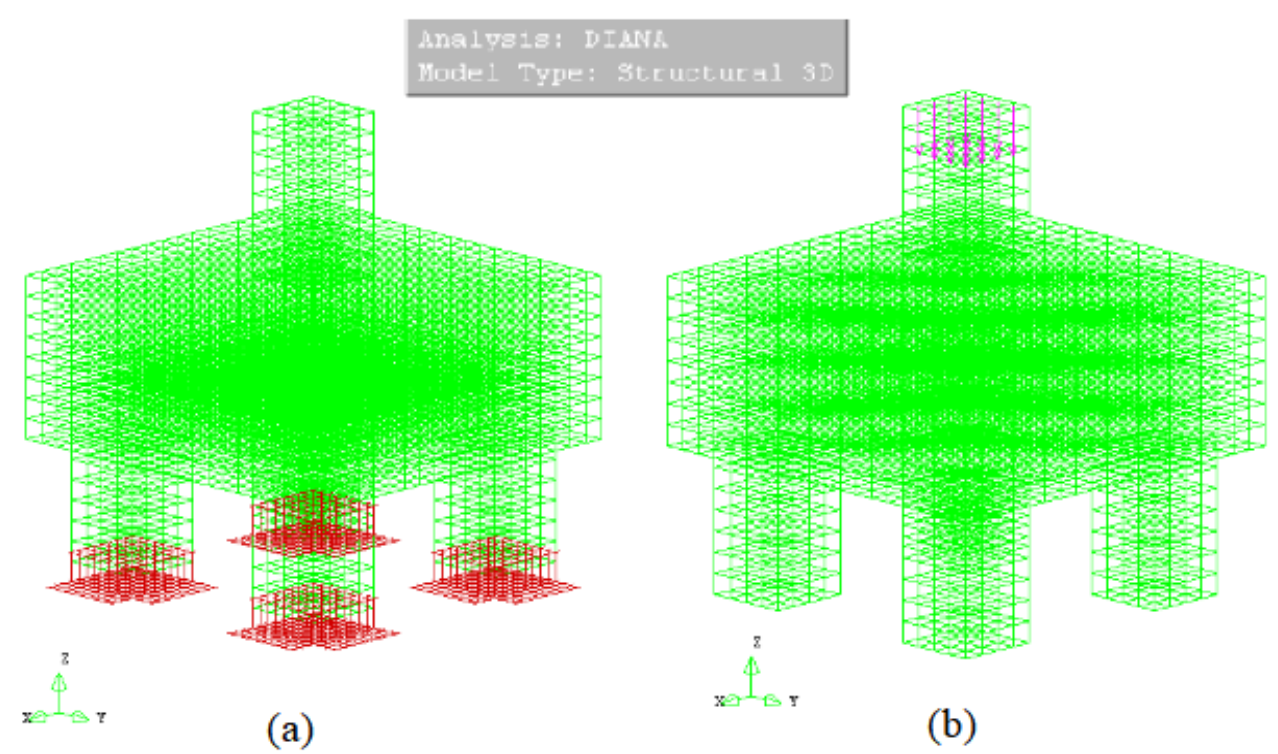

Figure 3. (a) Contour conditions in piles. (b) Action applied as pressure on the pillar.

The piles and pillar were modeled considering C50 concrete and the cap with C20 concrete, since the purpose of the study is to analyze the cap. Table 2 describes the concrete physical properties of the caps, piles and pillars.

Table 2. Physical properties of concretes.

\begin{tabular}{cccccc}
\hline & $\begin{array}{c}\text { Compressive strength } \\
\mathbf{f}_{\mathbf{c m}}(\mathbf{M P a})\end{array}$ & $\begin{array}{c}\text { Tensile strength } \\
\mathbf{f}_{\mathbf{c t}, \mathbf{m}} \mathbf{( M P a )}\end{array}$ & $\begin{array}{c}\text { Modulus of } \\
\text { elasticity } \mathbf{E}_{\mathbf{c s}}(\mathbf{M P a})\end{array}$ & Poisson's ratio v & $\begin{array}{c}\text { Energy of fracture } \mathbf{G}_{\mathbf{f}} \\
\left(\mathbf{N} . \mathbf{m m} / \mathbf{m m}^{\mathbf{2}}\right)\end{array}$ \\
\hline Cap & 20 & 2.21 & 21287.37 & 0.2 & 0.048735 \\
\hline Pillar & 50 & - & 33658.28 & 0.2 & - \\
\hline Pile & 50 & - & 33658.28 & 0.2 & - \\
\hline
\end{tabular}

The reinforcement steel considered a modulus of elasticity of $210 \mathrm{GPa}$, Poisson's ratio of 0.3 and characteristic yield strength of $500 \mathrm{MPa}$.

A pressure of $1 \mathrm{MPa}$ was applied to the top of the pillar. Consequently, the program makes an increase to the same pressure value, while permitted, and the actual program corrects the increased value if necessary. For the distributed cracking model used a maximum number of 50 interactions was permitted.

\section{RESULTS AND DISCUSSIONS}

First, in the literature experimental data show that there is the drop in AAR-affected concrete mechanical properties compared to healthy concrete. There are two options to address the changes in the mechanical properties, reported as influenced by the type of reactive aggregate, environmental conditions and stress state. One alternative consists of directly using the value of the properties of the material tested in the analysis. The other option evaluates the compressive and tensile stresses, and the modulus of elasticity as a result of the free expansion based on constitutive equations. Both options disregarded the directional nature of the degradation in the mechanical properties caused by the stress level. The first approach was adopted in the study and implemented in the analysis program. 
The reductions established in the study by Sanchez et al. [3], described in Table 3, were applied in order to study the distribution of cracking in the cracking fields along these reductions.

Table 3. Reduction rates in the mechanical properties of concrete submitted to AAR according to the expansion level.

\begin{tabular}{|c|c|c|c|c|c|c|c|c|c|}
\hline \multirow{3}{*}{$\begin{array}{c}\text { Expansion } \\
\text { level } \\
\text { benchmark } \\
(\%)\end{array}$} & \multirow{2}{*}{\multicolumn{3}{|c|}{$\begin{array}{l}\text { Minimum values } \\
\text { Reduction by AAR }\end{array}$}} & \multirow{2}{*}{\multicolumn{3}{|c|}{$\begin{array}{c}\text { Average values } \\
\text { Reduction by AAR }\end{array}$}} & \multirow{2}{*}{\multicolumn{3}{|c|}{$\begin{array}{l}\text { Maximum values } \\
\text { Reduction by AAR }\end{array}$}} \\
\hline & & & & & & & & & \\
\hline & $\begin{array}{l}\text { Modulus } \\
\text { of } \\
\text { elasticity } \\
(\%) \\
\end{array}$ & $\begin{array}{l}\text { Compressive } \\
\text { strength }(\%)\end{array}$ & $\begin{array}{l}\text { Tensile } \\
\text { strength } \\
\quad(\%)\end{array}$ & $\begin{array}{l}\text { Modulus } \\
\text { of } \\
\text { elasticity } \\
(\%) \\
\end{array}$ & $\begin{array}{l}\text { Compressive } \\
\text { strength }(\%)\end{array}$ & $\begin{array}{c}\text { Tensile } \\
\text { strength } \\
(\%)\end{array}$ & $\begin{array}{c}\text { Modulus } \\
\text { of } \\
\text { elasticity } \\
(\%) \\
\end{array}$ & $\begin{array}{l}\text { Compressive } \\
\text { strength }(\%)\end{array}$ & $\begin{array}{c}\text { Tensile } \\
\text { strength } \\
(\%)\end{array}$ \\
\hline 0 & 0 & 0 & 0 & 0 & 0 & 0 & 0 & 0 & 0 \\
\hline 0.05 & 5 & 0 & 15 & 21 & 8 & 38 & 37 & 15 & 60 \\
\hline 0.12 & 20 & 5 & 40 & 35 & 13 & 53 & 50 & 20 & 65 \\
\hline 0.2 & 35 & 13 & 45 & 48 & 19 & 58 & 60 & 25 & 70 \\
\hline 0.3 & 40 & 20 & 50 & 54 & 28 & 63 & 67 & 35 & 75 \\
\hline
\end{tabular}

Source: Adapted from Sanchez et al. [3].

Although the analysis of the reductions in the mechanical properties as a result of the expansion due to the AAR is complicated, and there are many contradictory results in the literature, the choice of parameters studied by Sanchez et al. [3] was due, from among the authors that related the degradation of concrete mechanical properties to the expansion due to the AAR, described herein, and is experimental study that provided the most complete parameters on the subject.

The first model was called a benchmark model in which reduction rates were not applied to the mechanical properties due to the AAR. Then there are the models numbers 1 to 4,5 to 8 and 9 to 12 , to which the minimum, average and maximum reduction rates of the mechanical properties were applied according to the expansion level. Table 4 shows the input data in the program for these models.

Table 4. Input data of models.

\begin{tabular}{|c|c|c|c|c|c|}
\hline $\begin{array}{c}\text { Models } \\
\text { (four-pile caps) }\end{array}$ & $\begin{array}{c}\text { Modulus of elasticity } \\
\text { (MPa) }\end{array}$ & $\begin{array}{c}\text { Compressive strength } \\
\text { (MPa) }\end{array}$ & $\begin{array}{c}\text { Tensile strength } \\
(\mathrm{MPa})\end{array}$ & $\begin{array}{c}\text { Expansion level } \\
(\%)\end{array}$ & $\begin{array}{c}\text { Length of crack } \\
\text { band h (mm) }\end{array}$ \\
\hline Benchmark & 21287.37 & 20 & 2.21 & 0 & 18.52764 \\
\hline \multicolumn{6}{|c|}{ Minimum values of reduction in mechanical properties due to AAR } \\
\hline 1 & 20223.00 & 20 & 1.88 & 0.05 & 21.79772 \\
\hline 2 & 16598.69 & 19 & 1.28 & 0.12 & 30.82667 \\
\hline 3 & 12906.09 & 17,4 & 1.11 & 0.2 & 33.53064 \\
\hline 4 & 11424.00 & 16 & 0.95 & 0.3 & 36.78072 \\
\hline \multicolumn{6}{|c|}{ Average values of reduction in mechanical properties due to AAR } \\
\hline 5 & 16130.32 & 18.4 & 1.29 & 0.05 & 29.80036 \\
\hline 6 & 12906.09 & 17.4 & 0.95 & 0.12 & 39.23798 \\
\hline 7 & 9962.49 & 16.2 & 0.81 & 0.2 & 43.80475 \\
\hline 8 & 8308.95 & 14.4 & 0.66 & 0.3 & 49.52947 \\
\hline \multicolumn{6}{|c|}{ Maximum values of reduction in mechanical properties due to AAR } \\
\hline 9 & 12364.37 & 17 & 0.79 & 0.05 & 46.06882 \\
\hline 10 & 9520.00 & 16 & 0.67 & 0.12 & 52.54389 \\
\hline 11 & 7374.16 & 15 & 0.55 & 0.2 & 61.16945 \\
\hline 12 & 5663.60 & 13 & 0.41 & 0.3 & 73.05412 \\
\hline
\end{tabular}

Table 5 and Figure 4 provide the results relating a maximum crack opening (mm) and expansion level (\%) of the models studied for the ultimate force of each model. It is found that the maximum opening of cracks increases with the expansion level. This crack opening behavior can be explained through the damage model used in the numerical simulation.

The Smeared Crack Model treats concrete as a heterogeneous material, which when accompanied by reinforcement, is able to form multiple small cracks, which in high load stages will combine and form one major crack or more [35]. 


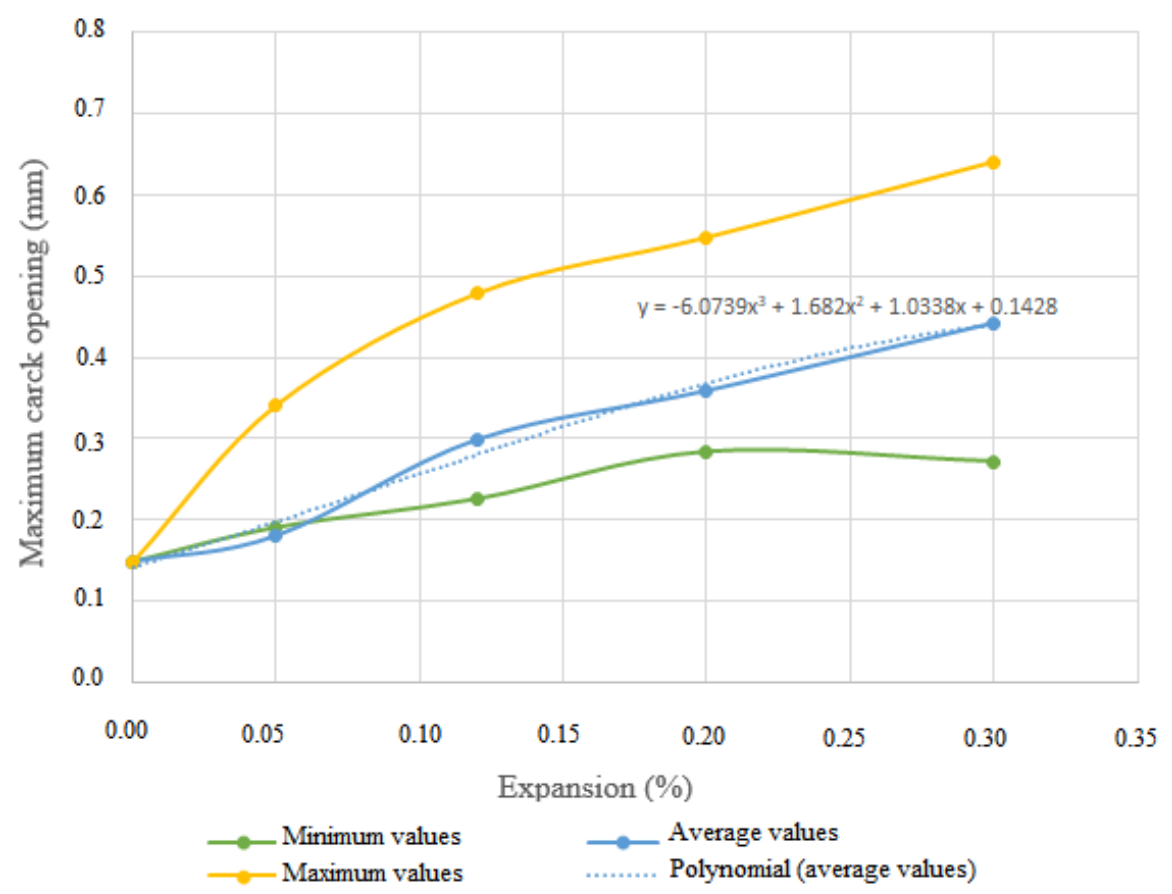

Figure 4. Maximum crack opening versus expansion level.

Table 5. Maximum crack opening versus expansion level.

\begin{tabular}{ccc}
\hline Models (four-pile caps) & Expansion level (\%) & Maximum crack opening (mm) \\
\hline Benchmark & 0 & 0.149 \\
\hline 1 & Minimum values of reduction in mechanical properties due to AAR & 0.191 \\
\hline 2 & 0.05 & 0.226 \\
\hline 3 & 0.12 & 0.284 \\
\hline 4 & 0.2 & 0.272 \\
\hline & 0.3 & 0.181 \\
\hline 6 & Average values of reduction in mechanical properties due to AAR \\
\hline 7 & 0.05 & 0.299 \\
\hline 8 & 0.12 & 0.359 \\
\hline 9 & 0.2 & 0.442 \\
\hline 10 & 0.3 & 0.342 \\
\hline 11 & Maximum values of reduction in mechanical properties due to AAR \\
\hline 12 & 0.05 & 0.479 \\
\hline
\end{tabular}

The crack opening for foundation caps must have a restricted value since they are structures in direct contact with the ground. Standard NBR 6118 [34] makes reference to openings of less than $0.3 \mathrm{~mm}$ in elements of environmental aggressiveness class II and III. So, the benchmark model (without AAR) is within that set out by the standard. For models with reductions due to the AAR, the models had crack openings of more than $0.3 \mathrm{~mm}$ based on the average reductions in the $0.2 \%$ expansion level.

Figures 5 and 6 show cracking fields in the failure for the non-AAR model and for the model with maximum reduction rate of AAR-affected mechanical properties, respectively. The cracking fields show crack openings wider than $0.1 \mathrm{~mm}$. For the AAR-affected foundation caps the main visual inspection points to check the cracking are the top part of the cap and side surfaces. 


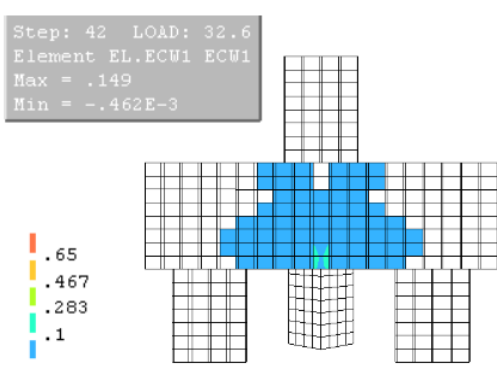

(a)

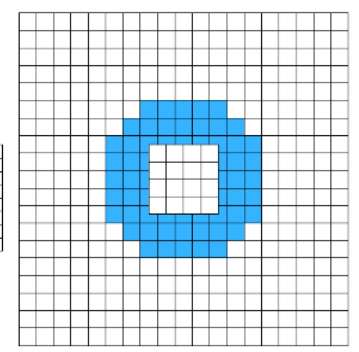

(b)

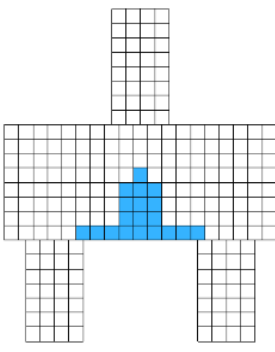

(c)

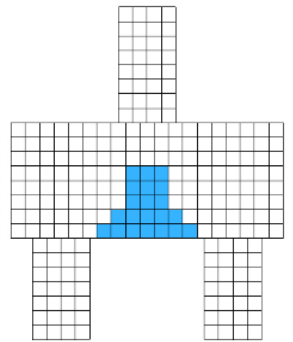

(d)

Figure 5. Cracking fields in failure for the benchmark model (without AAR), with indication of openings wider than $0.1 \mathrm{~mm}$. (a) diagonal section of cap; (b) top view; (c) and (d) side views.

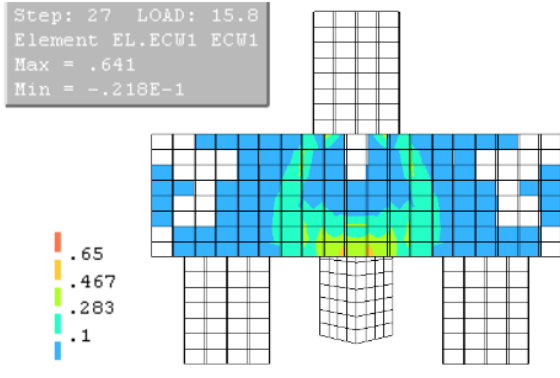

(a)

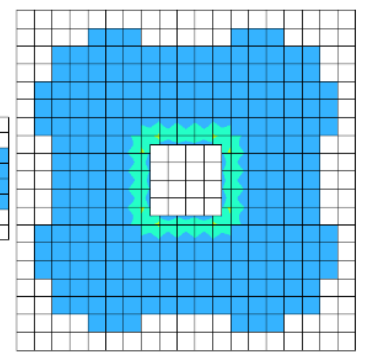

(b)

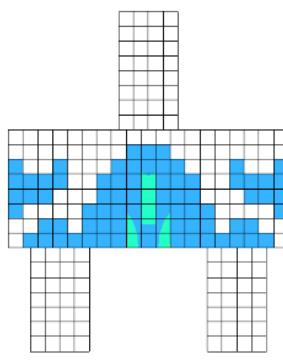

(c)

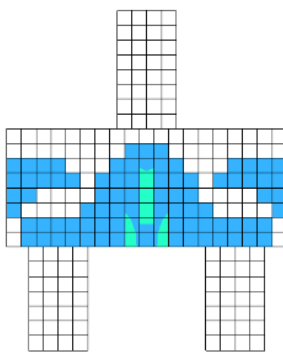

(d)

Figure 6. Cracking fields in failure for model 12 (Maximum values of reduction in mechanical properties due to AAR - expansion rate $0.3 \%$ ), with indication of openings wider than $0.1 \mathrm{~mm}$. (a) diagonal section of cap; (b) top view; (c) e (d) side views.

In general, the cracking fields clearly showed an increase in AAR due to the expansion rate, since the crack opening tended to widen. And this is in accordance with distributed cracking model adopted in the simulation, where the cracks spread along the element after the load was applied.

It may also be found that the wider cracks occurred at the cap bases, close to the cap centers (directly below the pillars' position), confirming the places where the major strains of the structure occur.

According to Meléndez et al. [36], one of the main failure modes in four-pile foundation caps is shearing in the rod due to cracks caused by the concrete's compressive softening. It was, therefore, found that the AAR models had more cracks in the rod region, thereby further impairing the cap's capacity. Probably the cause is the perpendicular tensile stress on the rod.

\section{CONCLUSIONS}

The reduction in mechanical properties impacted the crack opening. It is found that the cracks widen in size and quantity according to the increase in the expansion level (from $0.05 \%$ to $0.30 \%$ ).

The distributed crack model used by the program is able to form multiple small cracks per unit of length, distributed over a certain area. These cracks may spread as unit cracks after loading, providing higher values than reported in the article, which is consistent with results in AAR-impacted structures.

AAR models were found to have more cracks in the region of the rods, further impairing the cap capacity. It is likely that the cause is the perpendicular tensile stress on the rod.

As the expansion level increases the load from the start of cracking was less consistent with the structure's state of degradation due to AAR action.

In general, the cracking fields clearly portray the expected result for AAR-affected concretes. The crack openings were relatively wider in models with reductions in the mechanical properties due to the AAR than for the non-AAR model.

After the different simulations performed it may be said that the non-linear analysis for the AAR problem can accurately capture the behaviors referring to the cracking of the analyzed cap. 
Lastly, this study includes the understanding of the three main AAR impacts: expansion, cracking and degradation of the concrete's mechanical properties. And it is evident that the deterioration of the mechanical properties is related to AAR-induced expansion.

\section{ACKNOWLEDGEMENTS}

Thanks to the Coordination for the Improvement of Higher Education Personnel (CAPES).

\section{REFERENCES}

[1] E. A. O. Gomes, "Recuperação estrutural de blocos de fundações afetados pela Reação Álcali-Agregado - a experiência do Recife," M.S. thesis, Univ. Cat. Pernambuco, Recife, PE, 2008

[2] L. Sanchez, S. C. Kuperman, and P. Helene, "Using the accelerated Brazilian concrete prism test (ABCPT) to evaluate alkali aggregate reaction (AAR)," Rev. IBRACON Estrut. Mater., vol. 4, no. 4, pp. 575-581, 2011.

[3] L. Sanchez, B. Fournier, M. Jolin, J. Bastien, and D. Mitchell, "Tools for assessing damage in concrete affected by AAR coming from fine and coarse aggregates," Rev. IBRACON Estrut. Mater., vol. 10, no. 1, pp. 84-91, 2017.

[4] C. M. T. M. Gameleira, "Reduções das propriedades mecânicas do concreto devido à RAA na simulação de blocos sobre quatro estacas," Ph.D. dissertation, Univ. Fed. Pernambuco, Recife, PE, 2019.

[5] DIANA, Finite Element Analysis - Users Manual Release 9 - Analysis Procedures, 2005.

[6] DIANA, Finite Element Analysis - Users Manual release 9 - Material Library, 2005.

[7] DIANA, Finite Element Analysis - Users Manual Release 9 - Element Library, 2005.

[8] American Society for Testing and Materials, Standard Test Method for Determination of Length Change of Concrete due to AlkaliSilica Reaction, ASTM C-1293/08, 2008.

[9] Canadian Standards Association, Potential Expansivity of Aggregates - Procedure for Length Change due to Alkali-aggregate Reaction in Concrete Prisms - Methods of Test for Concrete, CSA A23.2-14A, 2014.

[10] I. Hafçi, "Effect of alkali-silica reaction expansion on mechanical properties of concrete," M.S. thesis, Middle East Tech. Univ., Turkey, 2013.

[11] H. Marzouk and S. Langdon, "The effect of alkali-aggregate reactivity on the mechanical properties of high and normal strength concrete," Cement Concr. Compos., vol. 25, no. 4-5, pp. 549-556, Jun 2003.

[12] N. P. Hasparyk, "Investigação de concretos afetados pela reação álcali-agregado e caracterização avançada do gel exsudado,” Ph.D. dissertation, Progr. Pós-grad. Eng. Civ., Univ. Fed. Rio Grande do Sul, Porto Alegre, 2005.

[13] D. W. Hobbs, Alkali-silica Reaction in Concrete. London: Thomas Telford, 1988.

[14] C. Larive, “Apport combinés de l'expérimentation et de la modélisation à la compréhension de l'alcali-réaction et ses effets mécaniques,” Ph.D. dissertation, Éc. Natl. Ponts Chaussées, Paris, France, 1997.

[15] D. A. St. John, “Alkali-aggregate reaction: New Zealand experience," in The Alkali-Silica Reaction in Concrete, R. N. Swamy, Ed., New York: Van Nostrand Reinhold, 1992.

[16] P. J. Nixon and R. Bollinghaus, "The effect of alkali aggregate reaction on the tensile strength of concrete," Durab. Build. Mater., vol. 2, pp. 243-248, 1985.

[17] N. Smaoui, M. A. Bérubé, B. Fournier, and B. Bissonnette, "Influence of specimen geometry, orientation of casting plane, and mode of concrete consolidation on expansion due to ASR," Cem. Concr. Aggreg., vol. 26, no. 2, pp. 58-70, 2004.

[18] N. Smaoui, M.-A. Bérubé, B. Fournier, B. Bissonnette, and B. Durand, "Evaluation of the expansion attained to date by concrete affected by ASR - Part I: experimental study," Can. J. Civ. Eng., vol. 31, no. 5, pp. 826-845, 2004.

[19] R. Pleau, M. A. Bérubé, M. Pigeon, B. Fournier, and S. Raphael, "Mechanical behavior of concrete affected by AAR,” in Proc. 8th Int. Conf. Alkali-Aggregate Reaction Concr., 1989.

[20] Institution of Structural Engineers, Structural Effects of Alkali-Silica Reaction. London: SETO, 1992.

[21] G. M. Wood and R. A. Johnson, “An engineer's perspective on UK - experience with alkali-aggregate reaction,” in Proc. 8th Int. Conf. Alkali-Aggregate Reaction Concr., 1989.

[22] G. M. Wood, P. Norris, and D. Leek, "Physical behavior of AAR damaged concrete in structures and in test conditions," in Proc. 8th Int. Conf. Alkali-Aggregate Reaction Concr.,' 1989.

[23] G. M. Wood and R. A. Johnson, The Appraisal and Maintenance of Structures with Alkali-silica Reaction. London: Institution of Structural Engineers, 1993.

[24] Y. Kubo and M. Nakata, "Effect of reactive aggregate on mechanical properties of concrete affected by alkali-silica reaction," in Proc. 14th Int. Conf. Alkali-Aggregate Reaction Concr., 2012. 
[25] R. Naar, "Modélisation du comportement mécanique du béton par approche multi-physique (couplage chimie-mécanique) application à la réaction alcali-silice,” Ph.D. dissertation, Éc. Natl. Supér. Min. Paris, Paris, France, 2010.

[26] L. F. M. Sanchez, B. Fournier, M. Jolin, D. Mitchell, and J. Bastien, "Overall assessment of Alkali-Aggregate Reaction (AAR) in concretes presenting different strengths and incorporating a wide range of reactive aggregate types and natures," Cement Concr. Res., vol. 93, pp. 17-31, 2017.

[27] R. V. Gorga, "Engineering-based FE approach to appraise slender structures affected by Alkali-Aggregate Reaction (AAR),” M.S. thesis, Dep. Civ. Eng., Univ. Ottawa, Ottawa, Ontario, Canada, 2018.

[28] J. G. Stoner, "Finite element modelling of GFRP reinforced concrete beams," Ph.D. dissertation, Univ. Waterloo, Ontario, Canada, 2015.

[29] B. Trunk and F. Wittmann, "Experimental investigation into the size dependence of fracture mechanics parameters," in Proc. 3rd Int. Conf. Fract. Mech. Concr. Struct., vol. 3, pp. 1937-1948, 1998.

[30] International Federation for Structural Concrete, Constitutive Modelling of High Strength/High Performance Concrete (Bulletin 42). Lausanne, Switzerland, 2008.

[31] Comite Euro-Internacional Du Béton, Model Code 2010 - First Complete Draft. Lausanne, Switzerland, 2010.

[32] Comite Euro-Internacional Du Béton, CEB-FIP: Model Code 1990 (Bulletin d'Information, 203-205). Paris: CEB-FIP, 1993.

[33] P. H. Feenstra and R. Borst, "Aspects of robust computational modeling for plain and reinforced concrete," Heron, vol. 38, no. 4, pp. 3-76, 1993.

[34] Associação Brasileira de Normas Técnicas, Concrete Structures Design, NBR 6118:2014, 2014.

[35] Borst, J. J. C. Remmers, A. Needleman, and M.-A. Abellan, "Discrete vs smeared crack models for concrete fracture: bridging the gap," Int. J. Numer. Anal. Methods Geomech., vol. 28, no. 78, pp. 583-607, 2004.

[36] C. Meléndez, J. Sagaseta, P. F. M. Sosa, and L. P. Rubio, "Refined three-dimensional strut-and-tie model for analysis and design of four-pile caps," ACI Struct. J., vol. 116, no. 4, pp. 15-29, Jul 2019.

Author contributions: C. M. T. M. Gameleira: conceptualization, formal analysis, writing, methodology. V. Q. G. Nunes: conceptualization, formal analysis, writing, methodology. P. A. Régis: supervision. P. M. V. Ribeiro: supervision. A. M. P. Carneiro: supervision. R. A. Oliveira: supervision, proofreading.

Editors: José Marcio Calixto, José Luiz Antunes de Oliveira e Sousa, Guilherme Aris Parsekian. 